\title{
Uma Flor Chamada Desejo: \\ Brasil e o poder na Língua Portuguesa
}

\section{Marcelo Calderari Miguel *}

Poeta nas terras capixabas, administrador, bibliotecário e docente na rede Estadual de Cursos Técnicos atua com projetos de Educação Financeira e Educação Patrimonial.

(iD) https://orcid.org/0000-0002-7876-9392

Recebido: 26 ago. 2020. Aprovado: 08 dez. 2020.

\section{Como citar este texto:}

MIGUEL, Calderari Marcelo. Uma Flor Chamada Desejo: Brasil e o poder na Língua Portuguesa. Revista Letras Raras. Campina Grande, v. 9, n. 4, p. 378-382, dez. 2020.

\section{A Última Flor do Lácio pelo Mundo}

Corruptos e corruptores do passado, do presente e, fatalmente, do vindouro.

Ponham suas barbas de molho, ponham-nas de molho, mesmo as mulheres sem barba.

A pátria Brasil caminha a galope ligeiro, ordeiro, vanguardeiro, alvissareiro e justiceiro.

Montada numa verdadeira e necessária democracia do povo, pelo povo e para o povo!

Para terminar, em bom e claro português apenas digo:

Isso, com exclamações, sem qualquer reticência para o futuro.

Companheiros, camaradas e comparsas - a cambada essa que acha que são - vamos lá!

E isso dá o que falar, não é um determinismo, pois o poder na língua portuguesa chama-se desejo.

$\triangle$ daymoura24@yahoo.com.br 


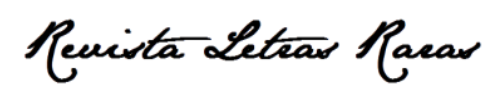

ISSN: 2317-2347 - v. 9, n. 4 (2020)

Todo o conteúdo da RLR está licenciado sob Creative Commons Atribuição 4.0 Internacional

\section{Laços Patriais e a Desejada Lusofonia?}

Vejo o Sabiá-laranjeira pousado em um Ipê-amarelo.

Num tronco resistente, levemente tortuoso, canta forte e assustada a tênue avezinha.

Mas que raro e singelo ver esse monumental e pátrio dueto!

Aquele que muito reza - é o que designa - o cordial vozear do sabiá.

O pé de ipê explana ideal firmeza - cascuda árvore nomeia que é.

Nos versos de Olavo Bilac ouço a língua portuguesa - tal poeta expressar uma singela lira.

Num ramo resistente, levemente aponta a última filhas do latim verdadeiramente absorvente.

Mas que insueto e bucólico ver esse monumental espetáculo de esplendor e sepultura!

Que aviva o rude e dolente dialeto - e muito o menciona o conclamar Veloso de Caetano.

Esta é a românica ou neolatina linguagem - nomeia por afinco a instância lusitana e colonizada.

A razão de viver é reconhecer patriais laços, nesse contexto se deseja a generosidade.

Sem generosidade não há comunidade, o prazer é colabor e vencer a jornada na saudade.

A Chama Desejo torga sem um rumo tomar; protesta assim a última flor do Lácio pelo mundo.

Haja fonoaudiologia educacional; ansiamo-nos redes lançar e alguma dádiva demonstrar.

A força motriz é aprendizado e corrente, expressão de duzentos e dez milhões por esses brasis. 


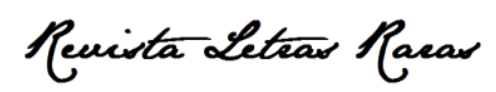

ISSN: 2317-2347 - v. 9 , n. 4 (2020)

Todo o conteúdo da RLR está licenciado sob Creative Commons Atribuição 4.0 Internacional

\section{Macunaíma, Brasil! Pia e Pião, Pardos são os Gatos Todas as Noites}

Todas as noites penso:

Minha cor parda é sem dor?

Qual cor, que etnia me pertençe?

A raça muitas vezes não é simplificador rotular.

Queria ter um laser certeiro para genética exata lhe informar.

Cientistas podem dizer ser subjetivo classificar, e outros nem isso dizem.

Logo pronunciar que está claro e evidente o visual tem o poder; hereditariza-se!

$\mathrm{Na}$ face, cara nua e dura do ser... Ato é certo e faceiro! A pele alimenta ou caracteriza? A expressão do Moreno, da doce canela e jambo ressalta os genótipos que definem o ser? Muitas são crenças, vasta as memórias, a raiz de uma adversa acuidade e salutar degradê. Fenótipos e genótipos de Michael de certa forma modificado? Hum... Jackson faz debate.

A estética inova o mito musical; a história da medicina pouco se atreve a polêmicas.

E a cinematográfica arte diz filosófica questão: à flor da pele é a pele que habito!

Até a ciência modifica a identidade, no funil a mestiçagem e a subjetividade:

muda a cor da pele, afina traços, seleciona genes na artificial índole.

Dor, rupturas e continuidades na formação plástica brasileira.

Geolocalizador e encontros e da boa reforma psiquiátrica.

Inquietações muitas e vastas em sapatilhas de balé.

Entre albinos, recessivos e dominantes eixos.

Somos todos iguais e diferentes seres.

A justiça é balança torta talvez.

Venda no olhar demonstra.

E uma mixar turbidez.

Imparcialidade fato!

Da mestiçagem.

Ser pardo é

Dilema

Brasil! 


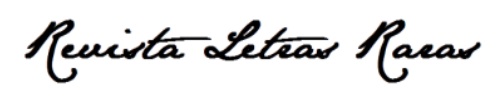

ISSN: 2317-2347 - v. 9, n. 4 (2020)

Todo o conteúdo da RLR está licenciado sob Creative Commons Atribuição 4.0 Internacional

\section{Poder na Língua: Ser ou Situar uma Lusófona Flor Inculta?}

Ser a flor da lusofonia é ser descendente e ascendente, é pautar rumos à multidão.

É uma bandeira, um mutirão, um de espaço de memória e apelo que a espelha a língua.

É ser forte, enfrentar dificuldades, sonhar com o seu lugar de fortuna, bem-estar e paixão.

É também situa um orgulhoso Ser que por vezes se envergonha de um colonizado passado.

Lusofonia é uma comunidade de povos e nação que se espalhou pelos sete descobertos mares.

Da pátria ufanista e amada de Brasil, Angola, Moçambique, Guiné Equatorial, Macau e Portugal.

Á terras como Timor-Leste, Guiné-Bissau, Cabo Verde e São Tomé e Príncipe já o reafirmam.

O português em Goa também está; o Concani toma legado e ciência dessa portuguesa língua.

A comunidade de mais de duzentos e quarenta milhões de pessoas segue planetária.

Uma materna língua compartilhada por dez países, unidos por um passado comum e híbrido.

E há especial comemoração, o quinto dia de maio é pura dedicação a essa cultural identidade.

Nisso Nossa Senhora da Conceição abençoa o idioma que faz nossa nação personalidade.

O português é o oitavo idioma mais falado no mundo, eis uma indescritível sensação.

A Conexão Lusófona expressa algo incomparável, uma colonização portuguesa é fato!

Também situa a histórica luta; território que se arrisca a mudar e glórias vivenciar.

O resistir se faz retentivo, histórico e calidoscópico; mister temor e saudade - mix de cafunés. 


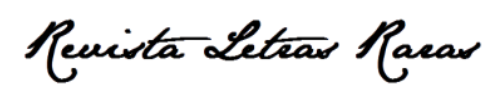

ISSN: 2317-2347 - v. 9, n. 4 (2020)

Todo o conteúdo da RLR está licenciado sob Creative Commons Atribuição 4.0 Internacional

\section{Ikigai dos Sentidos: Embarque dos Lusófonos Países}

Passa se anos e mais séculos... Tantos paradoxos na lbéria.

Há uma plausível medicação sobre uma língua pendular e plural.

O berço materno mostra vocábulos em um angular plano, quase real.

No fundo a fundo, nenhuma pessoa pode meu reviver o sonho de meu patuá.

Isso faz a roda girar, creio que isso é um trem particular! Todos buscam a interação alcançar.

Imagine o empreendimento do linguajar, avoca um planejado tempero de fito e rito sazonal.

Em sua esteira rotura vocábulos estratégicos, táticos e operacionais - enigmática teia forma.

Adentra um rol de missão, visão e valores de nossas peripécias, sátiras e aventuranças vastas.

Se assemelha ao que a própria biografia respeita - circula regras, exceções e reformas natas.

Assim o dialeto materno tende a virar, uma belo Oasis ou metáfora no situar de veleidades.

E as coisas marcham para o que se alvitrou - a empreendedora conivência e o equilíbrio.

Às vezes tal incubação deslancha a vida; linguajar atroz faz um refrigério tenaz!

Situa um drapeado figurativo, patrimonial e artístico de indumentária arte.

Capaz de dobrar verbais ou não verbais códigos com inerência vivaz.

Nisso a interconexão faz tecido, na oitava epopeia do mundo. 